Jurnal Bimbingan dan Konseling Ar-Rahman
Volume 7, Nomor 1, Tahun 2021
Tersedia Online: http://ojs.uniska.ac.id/index.php/BKA
e-ISSN 2477-6300

\title{
PENGEMBANGAN INVENTORI KECENDERUNGAN PERILAKU AGRESIF SISWA SMP
}

\author{
Fadhlina Rozzaqyah ${ }^{1}$, Silvia AR., Nur Wisma \\ Prodi Bimbingan dan Konseling, FKIP Universitas Sriwijaya, Jalan Palembang-Prabumulih KM 32, \\ Indralaya Universitas Sriwijaya \\ ${ }^{1}$ fadhlina@fkip.unsri.ac.id
}

\begin{abstract}
ABSTRAK
Agresivitas adalah tindakan seseorang dalam menyakiti orang atau benda lain. Penelitian ini bertujuan untuk menghasilkan inventori kecenderungan perilaku agresif peserta didik yang valid dan reliabel sehingga dapat digunakan sekolah dan atau konselor sekolah dalam mengidentifikasi kecenderungan siswa dalam bertindak agresif. Penelitian ini melibatkan 312 (70 orang pada uji tahap 3, 242 pada uji tahap 4) yang dipilih secara acak pada sekolah menengah pertama di Kabupaten Kayu Agung. Pengembangan inventori kecenderungan perilaku agresif menggunakan metode research and development dengan 5 tahap pengembangan ADDIE (analysis, design, development, implement, dan evaluation). Hasil penelitian pada tahap 3 menunjukkan seluruh item valid dengan nilai alpha cronbach's sebesar 0.778. Namun pada uji reliabilitas product moment ditemukan 6 item tidak reliabel sehingga dilakukan perbaikan konteks item pada 5 item dan 1 item dieliminasi. Sedangkan pada uji tahap 4 ditemukan 34 item dinyatakan valid dan reliabel dengan nilai alpha cronbach's sebesar 0,858 . Oleh karena itu inventori kecenderungan perilaku agresif telah teruji keterandalannya dan dapat dipublikasikan agar dapat digunakan oleh sekolah terutama konselor sekolah.
\end{abstract}

Kata Kunci: Inventori; Perilaku Agresif; ADDIE

\begin{abstract}
Aggressiveness is the act of a person hurting another person or object. This study aims to produce a valid and reliable inventory of aggressive behavior tendencies so that it can be used school or school counselors in identifying students' tendencies to act aggressively. This study involved 312 (70 studenst in the stage 3 test, 242 in the stage 4 test) randomly selected students in middle school in Kayu Agung Regency. The development of an aggressive behavior inventory uses the research and development method with 5 ADDIE development stages (analysis, design, development, implementation, and evaluation). The results of the research in stage 3 showed all valid items with a Cronbach's alpha value of 0.778. However, in the product-moment reliability test, it was found that 6 items were not reliable so that the context of the items was corrected for 5 items and 1 item was eliminated. In the stage 4 test, 34 items were found to be valid and reliable with a Cronbach's alpha value of 0.858. Therefore, the inventory of aggressive behavior has been proven reliable and can be published so that it can be used by schools, especially school counselors.
\end{abstract}

Keywords: Inventory; Aggressive Behavior; ADDIE

Dipublikasikan Oleh :

UPT Publikasi dan Pengelolaan Jurnal

Universitas Islam Kalimantan Muhammad Arsyad Al-Banjari Banjarmasin 
Fadhlina Rozzaqyah, Silvia AR., Nur Wisma

Jurnal Bimbingan dan Konseling Ar-Rahman

Volume 7, Nomor 1, Tahun 2021

e-ISSN 2477-6300

\section{PENDAHULUAN}

Pada anak-anak, dalam interaksi sosial beberapa dari mereka kerap menunjukkan rasa permusuhan atau perlawanan terhadap lingkungan dan orang lain. Perlawanan dan permusuhan ini menunjukkan bahwa pada diri individu kecenderungan berperilaku demikian merupakan bagian dalam perkembangan. Pada masa remaja, kecenderungan perilaku ini dapat semakin berkembang bahkan membentuk suatu kebiasaan berperilaku yang ditunjukkan secara fisik maupun verbal terhadap lingkungan dan orang lain di sekitarnya. Perilaku tersebut disebut sebagai perilaku agresif. Perilaku agresif atau kita kenal sebagai tindak kekerasan adalah salah satu bentuk tingkah laku sosial sebagai suau reaksi emosi yang meningkat pada remaja yang memasuki masa sekolah. (Hutomo \& Ariati, 2016).

Agresif menurut Myers dapat diartikan sebagai perilaku fisik atau verbal untuk menyakiti orang lain (Setiowati et al., 2017). Selanjutnya agresif juga dapat didefinisikan sebagai cara individu di mana fungsi dan tujuannya hanya untuk melukai orang lain dan diekspresikan secara langsung (fisik) seperti berkelahi, melukai, menyerang, membunuh, atau menghukum orang lain dan secara tidak langsung (Sidhu et al., 2019). Agresi memiliki banyak bentuk, mulai dari agresi sosial dan verbal atau kekerasan tidak langsung hingga agresi fisik dan jenis kekerasan yang lebih serius. (Hsieh \& Chen, 2017). Bentuk verbal merupakan bentuk agresi paling ringan seperti memanggil nama dengan sebutan kurang menyenangkan, sedangkan untuk agresi serius dapat berupa memukul, menendang atau meninju, hingga agresi berat yang berupa tindakan menusuk, menembak bahkan membunuh. (Allen \& Anderson, 2017). Bushman and Anderson mengungkapkan bentuk lain dari agresi yaitu agresi afektif dan instrumental. Agresi afektif adalah tindak kekerasan yang didasarkan pada perasaan negatif (kemarahan) dan agresi instrumental adalah tindak kekerasan yang dilakukan karena adanya tujuan dan relative tanpa dipengaruhi perasaan pelaku. (Benjamin, 2016). Berdasarkan pengertian dan bentuk agresif di atas, dapat disimpulkan bahwa kecenderungan perilaku agresif adalah kemungkinan seseorang untuk merugikan dan menyakiti orang lain maupun lingkungan dengan tindakan secara fisik maupun verbal yang dilakukan sebagai pengaruh dari perasaan maupun tujuan tertentu.

Agresivitas pada remaja dipengaruhi beberapa faktor. Faktor yang mempengaruhi perkembangan agresivitas remaja dapat berupa faktor pribadi, akdemik, keluarga, pengalaman, dan media (Estévez Lópe et al., 2018; Kaya et al., 2012; Wiedeman et al., 2015). Beberapa studi meta analisis juga menyimpulkan bahwa penggunaan alkohol pada remaja merupakan faktor pendorong yang kuat bagi munculnya perilaku agresif, pada dalam diri individu faktor kerentanan emosional, harga diri dan gaya permusuhan juga menjadi berbagai faktor terhadap pembentukan agresivitas. (Hastuti, 2018; Krahe, 2005).

Perilaku agresif pada remaja di Indonesia sendiri kerap menjadi isu yang memprihatinkan dan sering diberitakan diberbagai media informasi baik cetak maupun televisi dan media sosial. Unicef tahun 2016 menunjukkan bahwa kekerasan pada sesama remaja di Indonesia diperkirakan mencapai 50 persen. Hal ini didukung pada data kekerasan pada remaja pada tahun 2018. Dari total 445 kasus bidang pendidikan yang dilaporkan oleh Retno (Komisioner Komisi Perlindungan Anak Indonesia) sepanjang tahun ini, 51,20 persen atau 228 kasus terdiri dari kekerasan fisik dan kekerasan seksual yang kerap dilakukan oleh pendidik, kepala sekolah dan juga peserta didik. Kekerasan yang dilakukan oleh peserta didik remaja berupa tawuran, bullying, pelecehan seksual hingga kekerasan terhadap pendidik. Tak hanya kekerasan fisik. Komisi Perlindungan Anak Indonesia juga mencatat adanya peningkatan cyberbullying pada remaja, di mana pada tahun 2015 cyberbullying belum ditemukan pada remaja, namun dilaporkan terdapat 206 kasus pada tahun 2018. (Intan, 2018; Iro, 2018).

Tingginya kasus perilaku agresif di kalangan remaja menunjukkan perlu adanya pencegahan dini bagi anak dalam mengontrol emosi dan pemahaman etika dan moral yang baik di lingkungan keluarga dan sekolah. Terjadinya kasus kekerasan yang merugikan anak dan remaja kerap kali terungkap ketika korban agresivitas tersebut mengalami kerugian. Bahkan tak jarang kasus kekerasan ini diam-diam dilakukan oleh peserta didik dengan teman sebayanya.

Berdasarkan fenomena tingginya perilaku agresif dikalangan remaja Indonesia baik secara fisik maupun secara verbal, menunjukkan remaja Indonesia juga memiliki kecenderungan perilaku agresif. Kecenderungan perilaku agresif ini menunjukkan adanya suatu cikal bakal perilaku agresif. Oleh karena itu, pentingnya orang tua dan guru, khususnya guru Bimbingan dan Konseling mengetahui tingkat kecenderungan perilaku agresif pada remaja. Hal ini berkaitan untuk mencegah terjadinya perilaku agresif baru pada 
Fadhlina Rozzaqyah, Silvia AR., Nur Wisma

Jurnal Bimbingan dan Konseling Ar-Rahman

Volume 7, Nomor 1, Tahun 2021

e-ISSN 2477-6300

remaja dan mengembangkan penanganan terhadap perilaku agresif yang telah terjadi agar dapat dikontrol.

Kecenderungan perilaku agresif dapat diukur dengan mengembangkan inventori skala psikologi. Inventori ini bertujuan untuk mengetahui tingkat kecenderungan perilaku agresif peserta didik sehingga dapat dimanfaatkan sebagai inventori pengukuran kebutuhan peserta didik (need assesment) dan dasar dalam pelaksanaan layanan Bimbingan dan Konseling di Sekolah agar perilaku agresif peserta didik dapat dicegah untuk tidak terjadi dan mengurangi meluasnya perilaku agresif tersebut.

Pada beberapa studi pengembangan skala maupun inventori terkait perilaku agresif sudah dilakukan. Buss \& Perry (Saputra \& Handaka, 2017) mengembangkan skala perilaku agresif, skala ini ketika digunakan di Indonesia, dari 50 item skala, hanya 38 item yang dapat digunakan. Selain itu, skala perilaku agresif tersebut digunakan pada remaja dengan rentang usia 18 sampai 20 tahun. Selanjutnya, Denson et al. (2006) juga mengembangkan kuisioner agresivitas (aggression questionnaire atau AQ), kuisioner ini memuat perilaku agresif fisik dan verbal yang dikembangkan dengan responden pada tingkat perguruan tinggi. Kedua intstrumen pengukuran perilaku agresif di atas, perilaku agresif yang diukur berfokus kepada perilaku menyakiti dan merugikan orang lain yang dilakukan pada remaja akhir di Perguruan Tinggi, belum diuji pada remaja awal dengan karakteristik yang tentunya berbeda dengan usia remaja akhir.

Selanjutnya, pengembangan alat ukur perilaku agresif pada remaja awal dikembangkan oleh Orpinas \& Frankowski (2001), skala agresivitas yang dikembangkan tersebut berfokus pada perilaku agresif yang dilakukan pada remaja rata-rata usia 11-12 tahun dan dilakukan pada remaja dengan riwayat tindak kriminalitas terkait penggunaan senjata, perkelahian, penggunaan NAPZA dan Alkohol. Tentunya hal ini bertolak belakang dengan tujuan penyusunan inventori pada penelitian ini. Pada penelitian ini, inventori kecenderungan perilaku agresif dimaksudkan untuk mengukur kecenderungan peserta didik usia sekolah menengah pertama sebagai dasar guru BK dan sekolah dalam mencegah berkembangnya kecenderungan tersebut menjadi perilaku agresif hingga kriminalitas.

Berdasarkan uraian di atas, pentingnya pengembangan inventori kecenderungan perilaku agresif pada remaja dengan prosedur pengembangan yang memadai menunjukkan bahwa tujuan penelitian ini adalah menghasilkan inventori kecenderungan perilaku agresif yang valid dan reliabel.

\section{METODE}

Penelitian ini merupakan penelitian pengembangan (development research) yang bertujuan untuk mengembangkan inventori kecenderungan perilaku agresif. Populasi penelitian ini adalah siswa sekolah menengah pertama sederajat di kecamatan Pendopo, Kabupaten Empat Lawang sebanyak 1540 siswa dengan jumlah sampel sebanyak 313 siswa yang dipilih secara purposive sampling yaitu siswa yang mengikuti kelas tatap muka di masa pandemi covid-19. Dan sampel dibagi menjadi 2 jenis sampel, yaitu 70 siswa sebagai sampel untuk pengukuran validitas tahap 1 dan 242 siswa sebagai sampel untuk pengukuran validitas tahap 2, hal ini dilakukan untuk mengurangi bias terhadap data yang diperoleh.

Prosedur pengembangan inventori pada penelitian ini menggunakan desain pengembangan ADDIE. Model ADDIE ini adalah singkatan untuk lima tahap proses pengembangan, yaitu analysis (analisis), design (desain), develop (pengembangan), implement (implementasi), dan evaluate (evaluasi) dengan memperhatikan prosedur pengembangan skala psikologis sebagaimana berikut, (1) Identifikasi tujuan ukur, (2) Operasionalisasi konsep, (3) Penskalaan dan pemilihan format stimulus, (4) Penulisan item dan review item, (5) Uji coba, (6) Analisis item, (7) Kompilasi 1 seleksi item, (8) Pengujian reliabilitas dan validitas, dan (9) Kompilasi II format final. (Azwar, 2008). Adapun tahap penelitian dapat dilihat pada tabel 1 .

Untuk menghasilkan inventori kecenderungan perilaku agresif yang baik, maka pengembangan inventori ini mengacu pada syaratsyarat alat ukur atau instrumen yang baik. Persyaratan yang harus di penuhi oleh suatu instrumen pengukuran minimal ada dua macam, yaitu validitas dan reliabilitas. (Sukmadinata, 2008). Oleh karena itu, dalam penyusunan inventori kecenderungan perilaku agresif ini, validitas dan reliabilitas mutlak diperlukan.

Pengukuran validitas pada penelitian ini menggunakan dua bentuk validitas yaitu validitas isi dan validitas konstruk. Validitas isi terlihat dari sejauh mana butir-butir tes mencerminkan keseluruhan kawasan isi objek yang hendak diukur. Estimasi validitas ini tidak melalui penghitungan statistik akan tetapi melalui judgement subyektif dari para ahli. Validitas isi merupakan validitas yang diestimasi melalui pengujian terhadap isi tes dengan analisis rasional 
atau melalui pendapat profesional (professional judgement) para ahli. (Azwar, 2008). Sedangkan validitas konstruk adalah validitas yang menunjukan sejauh mana tes mengungkap suatu trait atau konstruk teoritik yang hendak diukurnya.
Validitas konstruk merupakan derajat yang menunjukan suatu tes mengukur sebuah konstruk sementara atau hypothetical construst. (Sukardi, 2007).

Tabel 1. Tahap Pengembangan ADDIE

\begin{tabular}{ll}
\hline Tahap Pengembangan & \multicolumn{1}{c}{ Prosedur penyusunan Skala Psikologis } \\
\hline Tahap 1. Analisis & $\begin{array}{l}\text { Identifikasi tujuan ukur } \\
\text { Operasionalisasi konsep }\end{array}$ \\
\hline Tahap 2. Desain & $\begin{array}{l}\text { Penskalaan dan pemilihan format stimulus } \\
\text { Penulisan item dan review item }\end{array}$ \\
\hline Tahap 3. Pengembangan & Uji coba (Validitas Isi, Validitas Konstruk dan Uji Reliabilitas 1) \\
& Analisis item \\
\hline Tahap 4. Implementasi & Kompilasi 1 seleksi item (evaluasi dan penyusunan inventori) \\
\hline Tahap 5. Evaluasi & Pengujian reliabilitas dan validitas konstruk 2 \\
& Kompilasi II format final (Penyusunan Inventori dan Petunjuk Penggunaan) \\
\hline
\end{tabular}

Pada validitas konstruk, teknik pengolahan data menggunakan aplikasi SPSS 21 dengan dua teknik analisis yaitu, analisis Pearson Product Moment pada tahap pengembangan dan analisis faktor pada tahap implementasi. Selanjutnya, untuk mengembangkan inventori kecenderungan perilaku agresif juga membutuhkan item inventori yang reliabel. Pengukuran reliabilitas pada penelitian ini menggunakan SPSS 21 dengan analisis Cronbach's Alpha. reliabilitas menunjuk pada konsistensi suatu alat ukur; artinya, jika suatu alat ukur digunakan untuk mengukur aspek atau atribut yang sama seharusnya hasil yang diperoleh relatif tidak berbeda. Adapun dasar pengambilan dalam uji reliabilitas adalah jika nilai Cronbach's Alpha $>0,60$ maka item dinyatakan reliabel atau konsisten.

\section{HASIL DAN PEMBAHASAN}

Pengembangan

inventori

kecenderungan perilaku agresif pada penelitian ini menggunakan 5 tahap pengembangan ADDIE seperti yang telah dijelaskan pada uraian sebelumnya.

\section{Tahap 1 Analisis}

Pada tahap ini, perumusan tujuan pengembangan alat ukur dan operasionalisasi konsep dilakukan secara internal bersama tim peneliti sehingga diperoleh hasil sebagai berikut.

1. Tujuan alat ukur

Tujuan penyusunan inventori kecenderungan perilaku agresif adalah untuk mengukur tingkat kecenderungan peserta didik dalam berperilaku agresif. Hasil pengukuran dapat dimanfaatkan dalam pengembangan layanan
Bimbingan dan Konseling di Sekolah dalam mencegah dan mengurangi perilaku agresif peserta didik

2. Definisi Operasional

Kecenderungan perilaku agresif peserta didik merupakan keinginan atau kemungkinan peserta didik untuk melakukan tindak perlawanan, permusuhan, menyakiti atau melukai orang lain dan merusak lingkungan baik secara fisik maupun verbal. Inventori kecenderungan perilaku agresif peserta didik disusun berdasarkan teori Sadli (Rozzaqyah et al., 2021) terkait aspek-aspek perilaku agresif, yaitu (1) pertahanan diri, (2) perlawanan disiplin, (3) egosentris, (4) superioritas, dan (5) prasangka yang diskemakan pada agresif fisik dan verbal.

\section{Tahap 2. Desain}

Tahap desain pada penelitian ini juga dilakukan secara internal bersama tim peneliti. Sehingga desain awal pengembangan inventori kecenderungan perilaku agresif dapat dilihat pada uraian berikut.

1. Penskalaan dan pemilihan format stimulus Penskalaan pada pengembangan inventori ini menggunakan skala likert, yaitu Sangat Sering (SS), Sering (S), Kadang-kadang (KK), Jarang (J), dan Tidak Pernah TP) yang disesuaikan pada item favorable dan unfavorable.

2. Penulisan item dan review item

Penulisan item dilakukan bersama-sama oleh tim peneliti yang selanjutnya diriview bersama sehingga menghasilkan inventori awal yang selanjutnya digunakan untuk validasi isi terhadap ahli. Pada tahap 2, desain pengembangan inventori secara umum 
Fadhlina Rozzaqyah, Silvia AR., Nur Wisma Jurnal Bimbingan dan Konseling Ar-Rahman Volume 7, Nomor 1, Tahun 2021

e-ISSN 2477-6300

memuat 3 sampai 4 butir pernyataan. Butir pernyataan disusun berdasarkan indikator pada aspek-aspek agresivitas. Adapun kisikisi pengembangan inventori pada tahap desain dapat dilihat pada tabel 2 .

\section{Tahap 3. Pengembangan}

Pada tahap ini, uji coba terhadap inventori pada tahap desain menggunakan uji validitas isi, konstruk dan uji reliabilitas. Pada kegiatan validitas isi, proses validitas dilakukan oleh 3 orang ahli, yaitu seorang psikolog, konselor sekolah, dan dosen bimbingan dan konseling yang berfokus pada penyusunan asesmen psikologi non tes, hasil validitas ahli diperoleh bahwa 35 item inventori dapat digunakan untuk uji coba selanjutnya dengan minor revisi. Sedangkan 1 item dihapus karena adanya kesamaan makna dengan inventori lain.

Selanjutnya pada uji validitas dan reliabilitas tahap 1, 35 item inventori tersebut selanjutnya diperbaiki dan diuji coba terhadap 70 orang remaja SMP. Hasil uji coba inventori dilakukan untuk melihat validitas dan reliabilitas inventori.

Hasil pengolahan data uji coba menunjukkan nilai alpha cronbach pada 35 item inventori kecenderungan sebesar 0.778 yang artinya lebh besar $>0.6$ sebagai standar reliabilitas suatu skala psikologi. Sehingga seluruh item inventori dinyatakan reliabel. Namun, pada pengukuran validitas menggunakan pearson product moment, ditemukan 6 item dari 35 item inventori menunjukkan $\mathrm{r}$ hitung $<\mathrm{r}$ tabel, yaitu $\mathrm{r}$ hitung lebih rendah dari $\mathrm{r}$ tabel $\mathrm{n} 70=0.2319$. Artinya keenam item tersebut harus diperbaiki atau dieliminasi.

Berdasarkan analisis proporsi terhadap item pada setiap aspek kecenderungan perilaku agresif, maka dari 6 item yang tidak valid tersebut diperbaiki sebanyak 5 item, sedangkan 1 item dieliminasi. Sehingga pada tahap 3 dikompilasi inventori terdiri dari 34 item. Adapun output SPSS reliabilitas dan validitas dapat dilihat pada tabel 3 dan 4.

Tabel 2. Kisi-kisi Inventori Kecenderungan Perilaku Agresif Tahap 2 (Desain)

\begin{tabular}{clccc}
\hline Aspek & \multicolumn{1}{c}{ Indikator } & No item (+) & No Item (-) & Jumlah \\
\hline Pertahanan Diri & Permusuhan & 5 & 1,2 & 3 \\
& Pemberontakan & 3 & 4,7 & 3 \\
& Pengerusakan & 9 & 8,11 & 3 \\
Perlawanan & Disiplin di lingkungan & 10 & 12,22 & 3 \\
Disiplin & Keluarga & & & \\
& Disiplin di lingkungan Sekolah & 14,35 & 21,23 & 4 \\
Egosentris & Kekuasaan dalam kelompok & 16,20 & 15,19 & 4 \\
& Kepemilikan & 13 & 17,29 & 3 \\
Superioritas & Tidak mau kalah & 18,27 & 33 & 3 \\
& Tidak mau diremehkan & 34 & 6,25, & 3 \\
Prasangka & Pandangan terhadap anggota & & $30,31,32$ & 3 \\
& kelurga & & & 3 \\
& Pandangan terhadap orang lain & 24 & 26,28 & 35 \\
\hline
\end{tabular}

Tabel 3. Output Reliabilitas Cronbach's Alpha Tahap 3 (Pengembangan)

\begin{tabular}{ccc}
\hline $\begin{array}{c}\text { Cronbach's } \\
\text { Alpha }\end{array}$ & $\begin{array}{c}\text { Cronbach's Alpha } \\
\text { Based on Standardized } \\
\text { Items }\end{array}$ & N of Items \\
\hline .778 & .790 & 35
\end{tabular}


Fadhlina Rozzaqyah, Silvia AR., Nur Wisma

Jurnal Bimbingan dan Konseling Ar-Rahman

Volume 7, Nomor 1, Tahun 2021

e-ISSN 2477-6300

Tabel 4. Output Validitas Product Moment Tahap 3 (Pengembangan)

\begin{tabular}{cccccc}
\hline $\begin{array}{c}\text { No } \\
\text { Item }\end{array}$ & $\begin{array}{c}\text { rxy } \\
\text { (r tabel N 70 } \\
\mathbf{0 . 2 3 1 9})\end{array}$ & $\begin{array}{c}\text { Keterangan } \\
\text { (Valid }= \\
\text { rxy } \mathbf{r} \text { tabel) }\end{array}$ & $\begin{array}{c}\text { No } \\
\text { Item }\end{array}$ & $\begin{array}{c}\text { rxy } \\
\text { (r tabel N 70 }= \\
\mathbf{0 . 2 3 1 9})\end{array}$ & $\begin{array}{c}\text { Keterangan } \\
\text { (Valid = } \\
\text { rxy }>\text { r tabel) }\end{array}$ \\
\hline 1 & 0.364 & Valid & 7 & 0.329 & Valid \\
2 & 0.374 & Valid & 8 & 0.058 & Tidak Valid \\
3 & 0.112 & Tidak Valid & 9 & 0.364 & Valid \\
4 & 0.406 & Valid & 10 & 0.081 & Tidak Valid \\
5 & 0.189 & Tidak Valid & 11 & 0.373 & Valid \\
6 & 0.335 & Valid & 12 & 0.168 & Tidak Valid \\
13 & 0.333 & Valid & 25 & 0.494 & Valid \\
14 & 0.187 & Tidak Valid & 26 & 0.301 & Valid \\
15 & 0.431 & Valid & 27 & 0.330 & Valid \\
16 & 0.593 & Valid & 28 & 0.360 & Valid \\
17 & 0.434 & Valid & 29 & 0.351 & Valid \\
18 & 0.361 & Valid & 30 & 0.450 & Valid \\
19 & 0.324 & Valid & 31 & 0.305 & Valid \\
20 & 0.349 & Valid & 32 & 0.388 & Valid \\
21 & 0.362 & Valid & 33 & 0.464 & Valid \\
22 & 0.552 & Valid & 34 & 0.429 & Valid \\
23 & 0.548 & Valid & 35 & 0.350 & Valid \\
24 & 0.392 & Valid & & & \\
\hline
\end{tabular}

\section{Tahap 4. Implementasi}

Pada tahap ini, implementasi inventori yang telah dievaluasi dan diseleksi menghasilkan inventori yang diharapkan lebih baik lagi. Adapun kisi-kisi inventori kecenderungan perilaku agresif pada tahap 5 dapat dilihat pada tabel 5 .

Pada tahap selanjutnya, 34 item inventori kecenderungan perilaku agresif kembali dilakukan uji coba terhadap 242 orang remaja SMP. Pada tahap ini (tahap 4) hasil uji coba meningkat dari sebelumnya. Diketahui seluruh item inventori dinyatakan valid dengan nilai alpha cronbach sebesar 0.858 seperti pada tabel 6 .

Selanjutnya pada uji validitas analisis faktor. Ada beberapa hal yang harus terpenuhi sebagai syarat analisis faktor, yaitu data berupa data kuantitatif, berdistribusi normal, dan matrik data memiliki korelasi yang cukup. Adapun syarat tersebut telah terpenuhi pada hasil pengukuran kecenderungan perilaku agresif peserta didik SMP dengan nilai uji normalitas data kolmogrovsmirnov diperoleh nilai Asymp. Signifikansi yaitu 0 yang artinya lebih kecil dari 0.05 .

Selanjutnya, nilai korelasi antar item dan indikator inventori dengan menggunakan uji Bartlett's Test of Shericity dan uji Kaiser-MeyerOlkin (KMO) dengan nilai signifikansi harus lebih besar dari 0,05 dan korelasi 0.30. Uji korelasi dilakukan pada tiga data, yaitu korelasi antar item inventori, korelasi antar indikator, dan korelasi antar aspek. Hasil uji barlett dan KMO pada tabel 5 menunjukkan nilai KMO peritem sebesar 0.810, per-indikator sebesar 0.896 , dan per-aspek dari inventori kecenderungan perilaku agresif sebesar 0.803. hasil ini menunjukkan adanya korelasi yang cukup kuat antar item, indikator dan aspek. Selanjutnya, Tabel 5 juga menunjukkan nilai signifikansi pada uji Bartlett's Test of Shericity adalah 0.000 yang artinya lebih kecil dari 0.05 . Hasil ini menunjukkan matrik data yang diperoleh dapat dilakukan analisis faktor.

Analisis faktor dilakukan pada item-item inventori yang memiliki nilai korelasi di atas 0.50 . Pada tabel 6, 34 item yang disusun mendapatkan hasil korelasi uji Measure of Sampling (MSA) semua di atas 0.50 dengan nilai terkecil 0.580 dan tertinggi 0.912 sehingga keseluruhan item tidak ada yang dieliminasi atau dibuang, dan dapat dilakukan analisis faktorial. Selanjutnya, dapat dilihat pada tabel 7, hasil uji principal component analysis (PCA) menunjukkan terdapat 11 faktor dengan persentase kumulatif $60.162 \%$ dengan factorial 1 mewakili 19.448\%. 11 faktor yang ditemukan pada analisis faktor uji PCA menunjukkan bahwa 11 faktor tersebut sesuai dengan kajian teori yang memuat 11 indikator sebagai faktor penyusunan inventori kecenderungan agresivitas. Untuk mempertegas 11 faktor tersebut, dapat dilihat pada tabel 8 dan gambar 1 yang menunjukkan scree plot item, hal ini menunjukkan adanya 11 titik faktor di atas nilai 1000, sebagai standar (initial) pada eigenvalues sebagai titik faktor, dengan nilai extraction 
Fadhlina Rozzaqyah, Silvia AR., Nur Wisma Jurnal Bimbingan dan Konseling Ar-Rahman Volume 7, Nomor 1, Tahun 2021

e-ISSN 2477-6300

communalities tidak ada di bawah 0.3 sehingga seluruh item dinyatakan valid.

Pada penelitian ini, hasil rotasi item menggunakan metode varimax tidak dilakukan sebagai pertimbangan untuk menjaga komposisi item pada setiap indikator inventori kecenderungan perilaku agresif. Oleh karena itu, dapat disimpulkan bahwa hasil analisis reliabilitas dan validitas konstruk analisis faktor menunjukkan inventori reliabel dan valid untuk dapat digunakan dalam mengukur tingkat kecenderungan perilaku agresif pada siswa SMP.

Tabel 5. Hasil Test Barlett dan KMO

\begin{tabular}{llrrr}
\hline & Per-item & Per-Indikator & Per-Aspek \\
\hline Kaiser-Meyer-Olkin Measure of Sampling Adequacy. & 0.810 & 0.896 & 0.803 \\
& Approx. Chi-Square & $2.075 \mathrm{E} 3$ & 653.477 & 317.798 \\
Bartlett's Test of Sphericity & Df & 561 & 55 & 10 \\
& Sig. & 0.000 & 0.000 & 0.000 \\
\hline
\end{tabular}

Tabel 6. Korelasi Uji Measure of Sampling (MSA)

\begin{tabular}{cc}
\hline $\begin{array}{c}\text { Nomor } \\
\text { Item }\end{array}$ & $\begin{array}{c}\text { Nilai Anti-Image } \\
\text { Correlation Item }\end{array}$ \\
\hline 1 & 0.772 \\
2 & 0.912 \\
3 & 0.792 \\
4 & 0.840 \\
5 & 0.600 \\
6 & 0.755 \\
7 & 0.833 \\
8 & 0.856 \\
9 & 0.580 \\
10 & 0.618 \\
11 & 0.813 \\
12 & 0.900 \\
13 & 0.613 \\
14 & 0.801 \\
15 & 0.845 \\
16 & 0.760 \\
17 & 0.857 \\
\hline
\end{tabular}

\begin{tabular}{cc}
$\begin{array}{c}\text { Nomor } \\
\text { Item }\end{array}$ & $\begin{array}{c}\text { Nilai Anti-Image } \\
\text { Correlation Item }\end{array}$ \\
\hline 18 & 0.680 \\
19 & 0.846 \\
20 & 0.665 \\
21 & 0.768 \\
22 & 0.903 \\
23 & 0.887 \\
24 & 0.787 \\
25 & 0.815 \\
26 & 0.807 \\
27 & 0.814 \\
28 & 0.808 \\
29 & 0.866 \\
30 & 0.800 \\
31 & 0.801 \\
32 & 0.806 \\
33 & 0.674 \\
34 & 0.693 \\
\hline
\end{tabular}

Tabel 7. Hasil Uji Principal Component Analysis (PCA)

\begin{tabular}{ccc}
\hline \multicolumn{3}{c}{ Extraction Sums of Squared Loadings } \\
\hline Total & \% of Varian & Kumulatif \% \\
\hline 6.612 & 19.448 & 19.448 \\
2.513 & 7.390 & 26.838 \\
1.620 & 4.764 & 31.601 \\
1.541 & 4.532 & 36.133 \\
1.361 & 4.003 & 40.136 \\
1.249 & 3.672 & 43.808 \\
1.175 & 3.457 & 47.265 \\
1.144 & 3.365 & 50.631 \\
1.142 & 3.359 & 53.990 \\
1.064 & 3.131 & 57.120 \\
1.034 & 3.042 & 60.162
\end{tabular}

Keterangan: Component $=$ Extraction $>$ Initial eigenvalues; Initial eigenvalues $=1000$

Dipublikasikan Oleh : 
Fadhlina Rozzaqyah, Silvia AR., Nur Wisma

Jurnal Bimbingan dan Konseling Ar-Rahman

Volume 7, Nomor 1, Tahun 2021

e-ISSN 2477-6300

Tabel 8. Initial Extraction Communalities (EC)

\begin{tabular}{ccccc}
\hline $\begin{array}{c}\text { Nomor } \\
\text { Item }\end{array}$ & $\begin{array}{c}\text { Nilai Extraction } \\
\text { Communalities }\end{array}$ & $\begin{array}{c}\text { Valid jika nilai } \\
\text { EC }>\text { 0.30 }\end{array}$ & $\begin{array}{c}\text { Nomor } \\
\text { Item }\end{array}$ & $\begin{array}{c}\text { Nilai Extraction } \\
\text { Communalities }\end{array}$ \\
\hline 1 & 0.771 & Valid & 18 & 0.662 \\
2 & 0.510 & Valid & 19 & 0.606 \\
3 & 0.450 & Valid & 20 & 0.530 \\
4 & 0.606 & Valid & 21 & 0.743 \\
5 & 0.657 & Valid & 22 & 0.457 \\
6 & 0.794 & Valid & 23 & 0.646 \\
7 & 0.568 & Valid & 24 & 0.659 \\
8 & 0.444 & Valid & 25 & 0.631 \\
9 & 0.629 & Valid & 26 & 0.683 \\
10 & 0.709 & Valid & 27 & 0.604 \\
11 & 0.548 & Valid & 28 & 0.606 \\
12 & 0.512 & Valid & 29 & 0.626 \\
13 & 0.618 & Valid & 30 & 0.548 \\
14 & 0.597 & Valid & 31 & 0.625 \\
15 & 0.599 & Valid & 32 & 0.525 \\
16 & 0.505 & Valid & 33 & 0.571 \\
17 & 0.689 & Valid & 34 & 0.528 \\
\hline
\end{tabular}

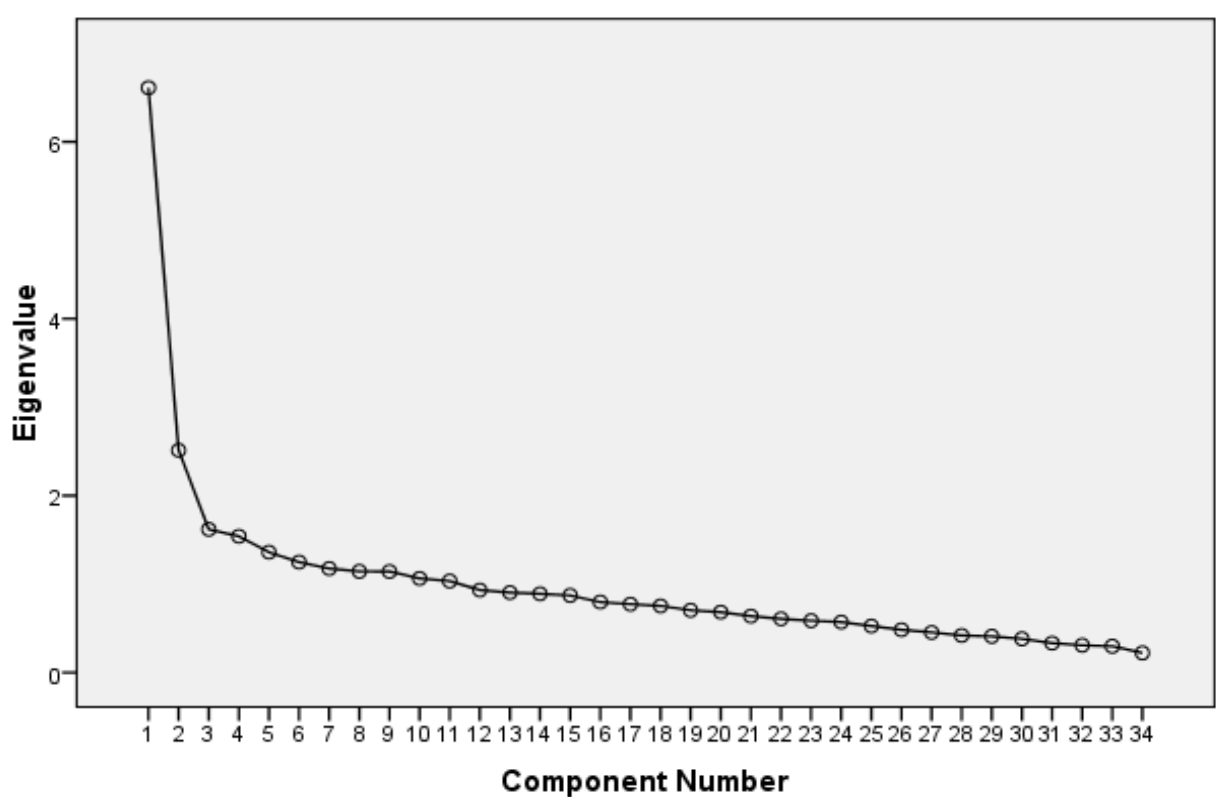

Gambar 1. Scree Plot

Tahap 5. Evaluasi

Selanjutnya hasil evaluasi terhadap uji reliabilitas dan validitas di atas merupakan tahap pengembangan ke 5 yaitu tahap evaluasi. Pada tahap ini, inventori disusun berdasarkan kisi-kisi pada tabel 8 .
Kisi-kisi inventori pada tabel 9 di atas menjadi dasar dalam penyusunan inventori kecenderungan perilaku agresif yang diimplementasikan dalam buku inventori yang memuat rasional inventori, tujuan inventori, petunjuk penggunaan hingga petunjuk interpretasi hasil penggunaan inventori. 
Tabel 9. Kisi-kisi Inventori Kecenderungan Perilaku Agresif Tahap Akhir

\begin{tabular}{|c|c|c|c|c|}
\hline Aspek Perilaku Agresif & Indikator & $\begin{array}{c}\text { No item } \\
(+)\end{array}$ & $\begin{array}{c}\text { No Item } \\
(-)\end{array}$ & Jumlah \\
\hline \multirow[t]{3}{*}{ Pertahanan Diri } & Permusuhan & 5 & 1,2 & 3 \\
\hline & Pemberontakan & 3 & 4,7 & 3 \\
\hline & Pengerusakan & 9 & 8,11 & 3 \\
\hline \multirow[t]{2}{*}{ Perlawanan Disiplin } & $\begin{array}{l}\text { Disiplin di lingkungan } \\
\text { Keluarga }\end{array}$ & 10 & 12,22 & 3 \\
\hline & $\begin{array}{l}\text { Disiplin di lingkungan } \\
\text { Sekolah }\end{array}$ & 14 & 21,23 & 3 \\
\hline \multirow[t]{2}{*}{ Egosentris } & $\begin{array}{l}\text { Kekuasaan dalam } \\
\text { kelompok }\end{array}$ & 16,20 & 15,19 & 4 \\
\hline & Kepemilikan & 13 & 17,29 & 3 \\
\hline \multirow[t]{2}{*}{ Superioritas } & Tidak mau kalah & 18,27 & 33 & 3 \\
\hline & Tidak mau diremehkan & 34 & 6,25 & 3 \\
\hline \multirow[t]{3}{*}{ Prasangka } & $\begin{array}{l}\text { Pandangan terhadap } \\
\text { anggota kelurga }\end{array}$ & & $\begin{array}{l}30,31 \\
32\end{array}$ & 3 \\
\hline & $\begin{array}{l}\text { Pandangan terhadap } \\
\text { orang lain }\end{array}$ & 24 & 26,28 & 3 \\
\hline & Jumlah & 12 & 22 & 34 \\
\hline
\end{tabular}

Pada praktiknya, baik psikolog, konselor maupun psikiater memerlukan pengukuran terhadap gejala yang tampak terhadap suatu situasi, sikap, persepsi, maupun karakteristik konseli. Penelitian psikologi dan praktik klinis sangat bergantung pada pengujian psikometri untuk mengukur konstruksi psikologis yang mewakili gejala psikopatologi, karakteristik perbedaan individu, atau profil kognitif. (Aldridge et al., 2017). Pada penelitian ini, inventori kecenderungan perilaku agresif disusun untuk menggambarkan intensitas remaja Sekolah Menengah Pertama terkait sikap dan profil kognitifnya dalam menghadapi situasi dan mengatasinya untuk menyakiti atau tidak menyakiti orang lain dan lingkungannya baik secara fisik maupun verbal.

Hasil di atas menunjukkan adanya perbedaan hasil validitas pada uji coba terhadap responden pertama dan responden kedua. Pada tahap uji coba reponden pertama, terdapat 5 item yang diperbaiki secara konstruk dan bahasa. Suatu alat ukur dikatakan memiliki validitas lemah dapat dipengaruhi beberapa faktor, salah satunya adalah penulisan item yang tidak mengikuti kaidah penulisan yang benar. (Muhid et al., 2015). Uji validitas sangat penting dalam pengembangan inventori atau alat ukur suatu penelitian. Validitas suatu alat ukur sangat menentukan keabsahan suatu informasi yang ingin peneliti temukan. Validitas menjelaskan seberapa baik data yang dikumpulkan mencakup area penelitian sebenarnya atau mengukur apa yang diinginkan oleh peneliti. (Field, 2005; Ghauri \& Gronhaug, 2005). Pada penelitian ini, dengan diubahnya bahasa dan konstruk item pada pengujian kedua menunjukkan tingkat validitas per-item meningkat dan dikatakan seluruhnya valid. Sehingga inventori dapat digunakan dalam mengumpulkan informasi sebenarnya tingkat kecenderungan perilaku agresif remaja di sekolah menengah.

Hasil penelitian di atas juga menunjukkan baik pada pengujian pertama maupun pengujian kedua memiliki nilai alpha cronbach yang tinggi. Artinya inventori kecenderungan perilaku agresif yang dikembangkan pada penelitian ini reliabel atau dapat dilakukan pada pengukuran secara berulang pada responden lain atau pada remaja di sekolah menengah lain dan di lingkungan lainnya. Reliabilitas suatu alat ukur atau inventori menunjukkan adanya konsistensi terhadap hasil yang ditemukan atau adanya hasil yang sama ketika dilakukannya pengukuran ulang terhadap responden yang berbeda dengan kesamaan kriteria responden. (Huck, 2007). Pengukuran reliabilitas dengan menggunakan alpha cronbach juga dikatakan merupakan penghitungan yang dianggap paling tepat ketika menggunakan alat ukur dengan skala Likert. (Whitley, 2002).

Inventori kecenderungan perilaku agresif di atas untuk kemudian dapat digunakan untuk mengukur kecenderungan perilaku agresif pada siswa SMP atau remaja dengan memiliki karakteristik yang sama. Inventori ini dapat 
Fadhlina Rozzaqyah, Silvia AR., Nur Wisma

Jurnal Bimbingan dan Konseling Ar-Rahman

Volume 7, Nomor 1, Tahun 2021

e-ISSN 2477-6300

menjadi alternatif alat ukur non test yang dapat digunakan oleh guru BK dan sekolah SMP karena belum adanya inventori khusus yang dikembangkan sebelumnya terkait kecenderungan perilaku agresif, selain itu, inventori ini juga mengukur aspek psikologis terkait perilaku agresif fisik, verbal dan prasangka atau perasaan dan pikiran peserta didik yang nantinya dapat menjadi indikator kecenderungan perilaku agresif yang dapat dicegah melalui pengembangan program BK dan sekolah..

\section{PENUTUP}

Pengembangan suatu inventori menjadi dasar daalm memperoleh informasi terkait kebutuhan peserta didik dalam Bimbingan dan Konseling. Pengembangan inventori kecenderungan perilaku agresif siswa sekolah menengah menjadi suatu hal yang dirasa perlu untuk dilakukan untuk mengembangkan suatu program pencegahan terhadap perilaku agresif remaja khususnya di Indonesia. Hasil pengembangan inventori menunjukkan nilai reliabilitas alpha cronbach sebesar 0.858 dengan kriteria keandalan tinggi serta 34 item inventori dikatakan reliabel dengan nilai $r$ hitung $>r$ tabel yaitu $>0.138$. Oleh karena itu dapat disimpulkan bahwa inventori kecenderungan perilaku agresif yang dihasilkan valid dan reliabel sehingga diharapkan dapat digunakan oleh sekolah dan konselor sekolah.

\section{UCAPAN TERIMAKASIH}

Penelitian/publikasi artikel ini dibiayai oleh: Anggaran DIPA Badan Layanan Umum Universitas Sriwijaya Tahun Anggaran 2020. SP DIPA-023172677515/2020, Revisi ke 01 tanggal 16 Maret 2020. Sesuai SK Rektor No. Nomor 0685 / UN9 / SK.BUK.KP/2020 tanggal 15 Juli 2020.

\section{REFERENSI}

Aldridge, V. K., Dovey, T. M., \& Wade, A. (2017). Assessing test-retest reliability of psychological measures: Persistent methodological problems. European Psychologist, 22(4), 207-218. https://doi.org/10.1027/1016-9040/a000298.

Allen, J. J., \& Anderson, C. A. (2017). Aggression and Violence: Definitions and Distinctions. The Wiley Handbook of Violence and Aggression, January 2017, 1-14. https://doi.org/10.1002/9781119057574.whb va001.

Azwar, S. (2008). Sikap manusia: Teori dan pengukurannya (4th ed.). Pustaka Pelajar.

Benjamin, A. J. (2016). Aggression. Encyclopedia of Mental Health: Second Edition, 1, 33-39. https://doi.org/10.1016/B978-0-12-3970459.00198-1.

Denson, T. F., Pedersen, W. C., \& Miller, N. (2006). The displaced aggression questionnaire. Journal of Personality and Social Psychology, 90(6), 1032-1051. https://doi.org/10.1037/00223514.90.6.1032.

Estévez Lópe, E., Jiménez, T. I., \& Moreno, D. (2018). Aggressive behavior in adolescence as a predictor of personal, family, and school adjustment problems. Psicothema, 30(1), 66-73.

https://doi.org/10.7334/psicothema2016.294.

Field, A. P. (2005). Discovering statistics using SPSS. Sage Publication Inc.

Ghauri, P., \& Gronhaug, K. (2005). Research Methods in Business Studies. Prentice Hall.

Hastuti, L. W. (2018). Kontrol Diri dan Agresi : Tinjauan Meta-Analisis. Buletin Psikologi, 26(1), 42-53. https://doi.org/10.22146/buletinpsikologi.32 805.

Hsieh, I. J., \& Chen, Y. Y. (2017). Determinants of aggressive behavior: Interactive effects of emotional regulation and inhibitory control. PLoS ONE, 12(4), 1-9. https://doi.org/10.1371/journal.pone.017565 1 .

Huck, S. W. (2007). Reading statistics and research. Allyn \& Bacon.

Hutomo, M. R., \& Ariati, J. (2016). Kecenderungan Agresivitas Remaja Ditinjau Dari Jenis Kelamin Pada Siswa Smp Di Semarang. Empati: Jurnal Karya Ilmiah S1 Undip, 5(4), 776-779.

Intan, G. (2018). KPAI: Kasus Kekerasan Anak dalam Pendidikan Meningkat Tahun 2018. https://www.voaindonesia.com/a/kpaikasus-kekerasan-anak-dalam-pendidikanmeningkat-tahun-

2018/4718166.html\#: :text=KPAI\%3A

Kasus Kekerasan Anak dalam Pendidikan Meningkat Tahun 2018,-Terakhir kali diperbarui\&text=Trend pelanggaran hak anak dalam bidang.

Iro. (2018). Kekerasan Remaja Indonesia Mencapai $50 \quad$ Persen. https://fk.ugm.ac.id/kekerasan-remajaindonesia-mencapai-50-persen.

Kaya, F., Bilgin, H., \& Singer, M. I. (2012). Contributing factors to aggressive behaviors 
Fadhlina Rozzaqyah, Silvia AR., Nur Wisma

Jurnal Bimbingan dan Konseling Ar-Rahman

Volume 7, Nomor 1, Tahun 2021

e-ISSN 2477-6300

in high school students in turkey. Journal of

School Nursing, 28(1), 56-63. https://doi.org/10.1177/1059840511418669.

Krahe, B. (2005). Perilaku Agresif. Pustaka Pelajar.

Muhid, A., Suhadiyanto, \& Nurhidayat, D. (2015). Pengembangan alat ukur psikologi. 1-10.

Orpinas, P., \& Frankowski, R. (2001). The aggression scale: A self-report measure of aggressive behavior for young adolescents. Journal of Early Adolescence, 21(1), 50-67. https://doi.org/10.1177/02724316010210010 03.

Rozzaqyah, F., Silvia, A., \& Wisma, N. (2021). Aggressive Behavior: Comparative Study on Girls and Boys in The Middle School . 513, 416-420.

https://doi.org/10.2991/assehr.k.201230.139.

Saputra, W. N., \& Handaka, I. B. (2017). Analisis validitas dan reliabilitas skala perilaku agresi. Peran Bimbingan Dan Konseling Dalam Penguatan Pendidikan Karakter, 2001, 260-268.

Setiowati, E. A., Suprihatin, T., \& Rohmatun. (2017). Gambaran agresivitas anak dan remaja di area beresiko. Prosiding Teтu Ilmiah X Ikatan Psikologi Perkembangan Indonesia, 170-179.

Sidhu, T. K., Kaur, P., Sangha, N. K., \& Bansal, A. S. (2019). Aggression among adolescents - A cross-sectional study. 1(1), 21-26. https://doi.org/10.25259/AUJMSR

Sukardi. (2007). Metodologi Penelitian Pendidikan. Bumi Aksara.

Sukmadinata, N. S. (2008). Metode Penelitian Pendidikan. Remaja Rosdakarya.

Whitley, B. E. (2002). Principles of research and behavioral science. McGraw-Hill.

Wiedeman, A. M., Black, J. A., Dolle, A. L., Finney, E. J., \& Coker, K. L. (2015). Factors influencing the impact of aggressive and violent media on children and adolescents. Aggression and Violent Behavior, 25(December), 191-198. https://doi.org/10.1016/j.avb.2015.04.008 